\title{
Impact of Monetary Policy on Bank Credit since Reforms Period
}

\author{
Mahendra R. Mishra ${ }^{1 "}$ and Sunil S. Narwade ${ }^{2}$ \\ ${ }^{1}$ Department of Economics, K.J. Somaiya College of Arts and Commerce (Autonomous), Affiliated to University of Mumbai, \\ Maharashtra, India \\ ${ }^{2}$ Department of Economics, Dr. Babasaheb Ambedkar Marathwada University Aurangabad, Maharashtra, India \\ *Corresponding author: mahendra.r.mishra@gmail.com
}

\begin{abstract}
Does Bank Rate, Cash Reserve Ratio (CRR) and Statutory Liquidity Ratio (SLR) affect the bank credit? This question always comes in the mind of researchers, economist, academicians, and policymakers and to get the answer to it, many research activities and projects are carried out by them. This study is also on the same line. The study intends to examine the impact of monetary policy on bank credit since reforms period. The study uses multiple regression models to test the selected banking variables by using the time series data collected from RBI. The study found that there is an inverse relationship between CRR and bank credit, SLR and bank credit but there is no association between bank rate by RBI and bank credit by the scheduled commercial banks in India since reforms period.
\end{abstract}

Keywords: Bank credit, bank rate, cash reserve ratio, statutory liquidity ratio

The Scheduled Commercial Banks in India are very important for economic growth and development. The nexus between financial development and economic growth was first put forward by Joseph Schumpeter (1911) in his work on 'Financial Development and Economic Growth'. According to him, the kind of services which are provided by financial institutions such as mobilizing savings, evaluating projects, managing risk, monitoring managers and facilitating transactions etc. are important for any economy. It encourages technological innovation and thereby overall economic growth and development.

The Indian banking sector has undergone significant transformation since early 1990s. The major reforms were initiated by the economy during the same period. The banking sector reforms were one of the parts of financial sector reforms initiated by the Government of India during early 1990's. The major banking sector reforms have initiated by the Reserve Bank of India and Government of India in 1991 and 1998 with the help of two reports, and both the committee chaired by the M. Narasimham.
The major aim of the banking sector reforms was to increase operational flexibility measures, strengthening measures, competitive measures and developing technological and institutional infrastructure etc. There is a remarkable and rapid transformation has taken place in Indian banking sector in the post-reform period (RBI 1991) and the second committee recommendation was to modernizing the banking sector, better regulation and supervision, and introduction of prudential norms (RBI 1998). The financial and banking sector reforms have to produce essential transformation in the operation of commercial banks in India. The reforms have shifted the organization system, ownership pattern and operational activities of scheduled commercial banks and infused the system into the competitive environment. The reforms have forced all banking sector to restructure their banking activities to meet these challenges.

\section{Bank Rate, CRR and SLR}

According to the Committee on Financial System (CFS, 1991), the level and structure of interest 
rates and the way they are determined are very important not only for the achieving wider goal of macroeconomic management and for the providing a competitive environment to the financial institutions, but also for ensuring the financial strength of bank and financial institutions.

In India, before the banking and financial sector reforms in 1991, the structure of interest rate followed by Indian financial system was very rigid and complex, because it was under the administrative control. Along with various reforms in financial and banking sector, the committee of financial sector believed that the interest rates should be allowed to perform their main function of allocating scarce funds among the alternative uses for them, to do so the interest rate will have to allow to be determined by market forces. The committee proposes that the interest rate should be deregulated to achieve macroeconomic goals in the future.

In India, before the financial sector reforms 1991, another major factor that affected the banking performance of Scheduled Commercial Banks was the high requirement of cash reserve ratio and statutory liquidity ratio by Reserve Bank of India. At the time of reforms in banking sector 1991, the total requirement in term of CRR and SLR was around 63.5 percent. According to the committee report, the high rate of CRR and SLR were restricting banks to lend credit at the desirable manners.

In order to increase the lending capacity of Scheduled Commercial Banks, the committee recommended that the reduction of cash reserve ratio and statutory liquidity ratio. According to the committee view, the reduction of these variable requirement ratios will enable banks to allocate their resources on the flexible and efficient way to promote investment and production in agriculture, industry, and trade. Based on the recommendation of the Narasimham committee in 1991, it was implemented in a phased manner since 1993.

\section{Research Problem}

The committee on financial system 1991 has suggested the deregulation of administrative interest rate, reduction of CRR and SLR rate and authority has implemented it in a phased manner. Now the question comes in mind that 'Does Bank Rate, Cash Reserve Ratio (CRR) and Statutory Liquidity Ratio
(SLR) really affect the bank credit?' This question always comes in the mind of researchers, economist, academicians, and policymakers and to get the answer, many research activities are carried out by them. The study intends to examine the "Impact of monetary policy on bank credit since reforms period".

\section{Objectives of the Research}

The objectives of the research are very important because based on that researcher is able to concentrate on a specific line of their research work. The current research work is based on the following research objectives:

1. To study the trends of bank credit, bank rate, cash reserve ratio and statutory liquidity ratio since reforms period.

2. To examine the impact of monetary policy on bank credit since reforms period.

3. To suggest policy measures and its future research in the same line.

\section{Hypothesis}

The study is based on the following hypothesis and these hypotheses are framed as:

- Null $\mathbf{H}_{0}$ : There is no association of bank rate (BR), cash reserve ratio (CRR) and statutory liquidity ratio (SLR) with bank credit.

- Alt $\mathbf{H}_{1}$ : There is an association of bank rate (BR), cash reserve ratio (CRR) and statutory liquidity ratio (SLR) with bank credit.

\section{Research Methodology and Data Collection}

The study is based on secondary data only and used descriptive methods to evaluate the research work. The data collected from the Handbook of Statistics on Indian Economy published by Reserve Bank of India and various articles, journals published by national and international publication house. The collection of the research data is based on 24 years from 1991-92 to 2014-15.

The study uses a regression method to investigate the relationship between the selected variables. For this, the regression equation is framed as per the requirement of the study. The equation deals with four variables such as bank credit, bank rate, CRR and SLR in which bank credit is the 
dependent variable and bank rate, CRR and SLR are independent variables. With the help of this regression method, the researcher would like to find out whether bank credit depend on the selected independent variables or not? The relationship is very important for credit disbursement and then the overall economic growth of the nation.

\section{Overview of Bank Rate}

The term bank rate is defined as the rate charged by the central bank for the lending funds to the commercial banks. It influences the lending rates of commercial bank. If bank rate is higher commercial bank lending rate will also be higher. It is one of the quantitative methods applied by the central banks to increase and decrease the money supply or inflation in the economy.

\section{Overview of CRR}

As per the master circular of RBI/2014-15/91DBOD. No.Ret.BC.11/12.01.001/2014-15 section 42(1) of the RBI Act, 1934 the Reserve Bank of India having regard to the need of securing the monetary stability in the country, has prescribes the CRR for the Scheduled Commercial Banks without any floor or ceiling rate. At the time of financial and banking sector reforms in India, the cash reserve ratio was very high, it was around 15 percent but due to the committee recommendation, it has reduced in a phased manner. At present, the CRR rate is 4 percent of the total demand and time liabilities (DLT) of the Scheduled Commercial Banks.

\section{Overview of SLR}

In terms of Section 24 of the Banking Regulations Act, 1949, Scheduled Commercial Banks have to invest in unencumbered government and approved securities certain minimum amount as statutory liquidity ratio (SLR) on a daily basis. In addition to investment in unencumbered government and other approved securities, gold, cash and excess CRR balance are also treated as liquid assets for the purpose of SLR. At the time of banking sector reforms in India, the SLR was very high which affected the lending capacity of the Scheduled Commercial Banks. But due to the committee recommendation and implementation by respective authority, the SLR has reduced in phased manners. At present every scheduled commercial required to keep up to 19.5 percent SLR (RBI, 2015).

\section{RESULTS AND DISCUSSION}

To find out the association between selected banking variables, multiple regression equation is framed. The study uses time series data for the regression equation during the study period. The data collected for study work is actual data and for using these data for regression equation need normality test. To meet this, the time series data converted into log natural form because the log natural is important for fulfilling the normality assumption of the regression equation. The equation with its subequation deals with BR, CRR, SLR, and BC of the scheduled commercial banks since reforms period. The regression equation is as follows:

$$
Y=\beta_{0}+\beta_{1} X_{1}+\beta_{2} X_{2}+\beta_{3} X_{3}+\mu
$$

The regression equation is rearranged after the transformation of data to normalized data with $\ln (X)$ form, equation No. 1 can be written as:

$$
\ln Y=\beta_{0}+\beta_{1} \ln X_{1}+\beta_{2} \ln X_{2}+\beta_{3} \ln X_{3}+\mu
$$

Where: $Y$ : Bank Credit and it is Dependent Variable, $X_{1}$ : Bank Rate and $X_{2}$ : Cash Reserve Ratio (CRR) and $X_{3}$ : Statutory Liquidity Ratio (SLR) are Independent Variables. The $\beta_{0^{\prime}} \beta_{1^{\prime}} \beta_{2^{\prime}}$ and $\beta_{3}$ are the regression coefficients which are estimated from the sample data, the $\mu$ is the random error term. To show the association between the dependent variable and independent variables, the following hypotheses are framed:

- H0: There is no association of Bank Rate, Cash Reserve Ratio (CRR) and Statutory Liquidity Ratio (SLR) with Bank Credit.

- H1: There is an association of Bank Rate, Cash Reserve Ratio (CRR) and Statutory Liquidity Ratio (SLR) with Bank Credit.

Table 1: Regression Statistics of Bank Rate, CRR, SLR and Bank Credit

\begin{tabular}{cc}
\hline \multicolumn{2}{c}{ Regression Statistics: Based on 1991-92 to 2002-03 } \\
\hline Multiple R & 0.886143644 \\
R Square & 0.785250559 \\
Adjusted R Square & 0.704719518 \\
Standard Error & 0.36464095 \\
Observations & 12 \\
\hline
\end{tabular}




\begin{tabular}{cc}
\hline Regression Statistics: Based on 2003-04 to 2014-15 \\
\hline Multiple R & 0.983596 \\
R Square & 0.96746 \\
Adjusted R Square & 0.955258 \\
Standard Error & 0.118564 \\
Observations & 12 \\
\hline Regression Statistics: Based on 1991-92 to 2014-15 \\
\hline Multiple R & 0.875952 \\
R Square & 0.767291 \\
Adjusted R Square & 0.732385 \\
Standard Error & 0.66616 \\
Observations & 24 \\
\hline
\end{tabular}

Source: Self-calculation.

Table 1 shows the regression statistics of twophase of the study period and overall results of the multiple regression equations. During the study period of 1991-92 to 2002-03, and 2003-04 to 2014-15 and 1991-92 to 2014-15, the table shows the R and $\mathrm{R}^{2}$ which represent the multiple correlation and coefficient of determination respectively. The value of $\mathrm{R}$ is 0.88 percent, 0.98 percent, and 0.87 percent of all the study period shows that there is exist a very positive relationship with the Bank Credit (BC) as the dependent variable and bank rate, cash reserve ratio and statutory liquidity ratio as the independent variables. Therefore, it is implied that the trends and pattern of bank rate, cash reserve ratio and statutory liquidity ratio did influence total bank credit of the scheduled commercial banks for the period of 1991-92 to 2014-15.

Further, $\mathrm{R}^{2}$ which is coefficient of determination value of 0.78 percent in the first phase of the study period means that approximately 78 percent of the proportion of variation in $\mathrm{BC}$ is explained by all the independent variables. The value of $\mathrm{R}_{2}$ during the second phase of the study period is 0.96 percent means that approximately 96 percent of the proportion of variation in BC explained by the all independent variables. For the study period 1991-92 to 2014-15, $\mathrm{R}^{2}$ which is the coefficient of determination value of 0.78 means that approximately 78 percent of the proportion of variation in $\mathrm{BC}$ is explained by all the independent variables.

Moreover, the adjusted $\mathrm{R}^{2}$ coefficient of determination adjusted for the (degree of freedom) value of 70 percent, 95 percent and 73 percent in the line of $\mathrm{R}^{2}$ value already explained above for the study period. This also implies that during the all the phase of the study period, BR, CRR, and SLR explained around 70 percent, 95 percent and 73 percent of changes in BC.

Table 2 shows the analysis of variance used for the study purposes during the study period of 1991-92 to 2002-03, and 2003-04 to 2014-15 and overall 199192 to 2014-15. The table indicates that the Analysis of Variance (ANOVA) used to test the overall

Table 2: Analysis of Variance (ANOVA) based on Bank Rate, CRR and SLR and Bank Credit

\begin{tabular}{|c|c|c|c|c|c|}
\hline \multicolumn{6}{|c|}{ Based on 1991-92 to 2002-03 } \\
\hline & Df & SS & MS & $\mathbf{F}$ & Significance $\mathbf{F}$ \\
\hline Regression & 3 & 3.889529559 & 1.296509853 & 9.750905413 & $0.004762129^{*}$ \\
\hline Residual & 8 & 1.063704178 & 0.132963022 & & \\
\hline Total & 11 & 4.953233737 & & & \\
\hline \multicolumn{6}{|c|}{ Based on 2003-04 to 2014-15 } \\
\hline & df & SS & MS & $\mathrm{F}$ & Significance $\mathbf{F}$ \\
\hline Regression & 3 & 3.343618 & 1.114539 & 79.28431 & $2.72 \mathrm{E}-06^{*}$ \\
\hline Residual & 8 & 0.11246 & 0.014058 & & \\
\hline Total & 11 & 3.456078 & & & \\
\hline \multicolumn{6}{|c|}{ Based on 2003-04 to 2014-15 } \\
\hline & df & SS & MS & $\mathrm{F}$ & Significance $\mathbf{F}$ \\
\hline Regression & 3 & 29.26403 & 9.754678 & 21.98144 & $1.53 \mathrm{E}-06^{*}$ \\
\hline Residual & 20 & 8.875376 & 0.443769 & & \\
\hline Total & 23 & 38.13941 & & & \\
\hline
\end{tabular}

Source: Self-calculation; ${ }^{*}$ indicates significance at $5 \%$ as $p<0.05$. 
Table 3: Regression Coefficient of Bank Rate, CRR and SLR and Bank Credit

\begin{tabular}{|c|c|c|c|c|}
\hline \multicolumn{5}{|c|}{ Based on 1991-92 to 2002-03 } \\
\hline & Coefficients & Standard Error & t Stat & P-value \\
\hline Intercept & 39.71713442 & 13.18918166 & 3.011341828 & 0.016779222 \\
\hline $\ln X_{1}(\mathrm{BR})$ & 1.23053447 & 1.272447039 & 0.967061443 & 0.361835139 \\
\hline $\ln X_{2}(\mathrm{CRR})$ & 1.272662912 & 0.930665416 & 1.367476313 & 0.208657115 \\
\hline $\ln X_{3}(\mathrm{SLR})$ & -10.68585867 & 3.632774035 & -2.941514821 & $0.018666339^{*}$ \\
\hline \multicolumn{5}{|c|}{ Based on 2003-04 to 2014-15 } \\
\hline Intercept & 15.47708 & 1.083734 & 14.28125 & 5.64E-07 \\
\hline $\ln X_{1}(B R)$ & 0.860648 & 0.694676 & 1.238921 & 0.25049 \\
\hline $\ln X_{2}(C R R)$ & -1.2332 & 0.346787 & -3.55606 & $0.007443^{*}$ \\
\hline $\ln X_{3}(\mathrm{SLR})$ & -1.98105 & 0.52022 & -3.8081 & $0.005177^{*}$ \\
\hline \multicolumn{5}{|c|}{ Based on 1991-92 to 2014-15 } \\
\hline Intercept & 22.46024 & 4.970982 & 4.518271 & 0.00021 \\
\hline $\ln X_{1}(B R)$ & 0.717894 & 0.751119 & 0.955766 & 0.350601 \\
\hline $\ln X_{2}(\mathrm{CRR})$ & -1.81616 & 0.594396 & -3.05548 & $0.006244^{*}$ \\
\hline $\ln X_{3}(\mathrm{SLR})$ & -3.47813 & 1.832423 & -1.8981 & $0.072211^{* *}$ \\
\hline
\end{tabular}

Source: Self-calculation; *Indicates significance at $1 \%$ as $p<0.01,{ }^{* *}$ indicates significance at $10 \%$ as $p<0.1$.

significance of the regression model developed for the regression. The model significance is depending on the value of $\mathrm{F}$ significance which is less than 5 percent level. Table has examined the bank rate, cash reserve ratio and statutory liquidity ratio jointly explain $99 \%$ percent of the variance in BC. Also, since the F-value is extremely greater than 1 and is significant for the all study period, we can conclude that our regression model results in the significantly better prediction of $\mathrm{BC}$ than if we used the mean value of BC. In short, the regression model overall predicts BC statically significantly at $5 \%$.

Based on the result of the regression coefficient, Table 3 shows the multiple regression analysis to test the Null Hypothesis based on three phases of the study period, the first phase is from 1991-92 to 2002-03, the second phase is 2003-04 to 2014-15 and overall study period from 1991-92 to 2014-15.

The first phase of the study period from 1991-92 to 2002-03 of the regression results shows that there is no negative association between Bank Rate (BR), Cash Reserve Ratio (CRR) and Bank Credit (BC). Therefore, the null hypothesis for $\beta_{1}$ and $\beta_{2}$ is failed to reject. The results of regression equation show that the p-value of Statutory Liquidity Ratio (SLR) as p-value $<0.01$ or $1 \%$, in this case, the null hypothesis for $\beta_{3}$ is rejected as it shows that there is a negative association between Statutory Liquidity
Ratio (SLR) and Bank Credit. As Statutory Liquidity Ratio (SLR) decreases the bank credit or capacity to create credit of the scheduled commercial banks has increased during the study period.

The second phase of the study period from 200304 to 2014-15 of the regression result shows that there is no negative association between bank rate and bank credit. Therefore, the null hypothesis for $\beta_{1}$ is failed to reject. The results of regression equation show that the $p$-value of Cash Reserve Ratio (CRR) is as $p$-value $<0.01$ or $1 \%$, in this case, the null hypothesis for $\beta_{2}$ is rejected as it shows that there is a negative association between cash reserve ratio and bank credit. As Cash Reserve Ratio (CRR) declined, bank credit or capacity to create credit of the scheduled commercial banks increased. The results of the regression equation show that the p-value of Statutory Liquidity Ratio (SLR) is as p-value $<0.01$ or $1 \%$. In this case, the null hypothesis for $\beta_{3}$ is rejected as it shows that there is a negative association between Statutory Liquidity Ratio (SLR) and bank Credit. As Statutory Liquidity Ratio (SLR) decreases the bank credit or capacity to create credit of the scheduled commercial banks has increased during the study period.

The overall study period from 1991-92 to 2014-15 of the regression results shows that there is no negative association between bank rate and bank 
credit. Therefore, the null hypothesis for $\beta_{1}$ is failed to reject. The results of regression equation show that the p-value of Cash Reserve Ratio (CRR) is as $\mathrm{p}$-value $<0.01$ or $1 \%$, in this case, the null hypothesis for $\beta_{2}$ is rejected as it shows that there is a negative association between cash reserve ratio and bank credit. As Cash Reserve Ratio declined, bank credit or capacity to create credit of the scheduled commercial banks increased. The result of regression equation shows that the p-value of Statutory Liquidity Ratio (SLR) is as p-value < 0.1 or $10 \%$, in this case, the null hypothesis for $\beta_{3}$ is rejected as it shows that there is a negative association between statutory liquidity ratio (SLR) and bank credit. As Statutory Liquidity Ratio (SLR) decreases the bank credit or capacity to create credit of the scheduled commercial banks has increased during the study period.

\section{CONCLUSION}

The financial sector reforms initiated by the government have a good impact on bank credit. The CRR and SLR reduced in a phased manner and it has affected the credit creation capacity of the commercial banks. As per the study, the regression equation result shows that bank rate has no significant association with bank credit of the scheduled commercial banks since reforms period. The other two variables are significant with total bank credit of the scheduled commercial banks during the period. The result shows that there is a negative association between CRR and SLR with BC of the banks. It means, when CRR and SLR declining, it influence the bank credit creation capacity of the banks which leads to increase bank credit by the banks. The hypothesis framed for the study purpose and the results of the regression is as follows:

1. Regression result shows that the bank rate is not statistically significant to bank credit of the scheduled commercial banks during the study period. In this, the null hypothesis is failed to reject.
2. The regression result shows that the CRR and SLR are statistically significant to BC at 1 percent and 10 percent level of degree of freedom.

It shows that there is negative association between CRR, SLR, and BC. It indicates that lower CRR and SLR can boost BC in the economy. The null hypothesis in this case is rejected. The overall study found that the RBI monetary policy has a huge impact on gross bank credit of the scheduled commercial banks for the study period 1991-92 to 2014-15.

\section{REFERENCES}

Kothari, R.C. 2004. Research Methodology: Methods and Techniques. Second Edition, New Age International Publisher, New Delhi, India.

Kumar Ranjit. 2011. Research Methodology: A step by step Guide for beginners. Third Edition, Sage Publication, New Delhi.

Narasimham, M. 1991. Report of the Committee on Banking Sector Reforms. Reserve Bank of India, Committee Report, Ministry of Finance, Government of India, Mumbai.

Reserve bank of India: 2015-16. Handbook of Statistics of the Indian Economy 2015-16. Reserve bank of India Publication, Mumbai, India.

Reserve Bank of India: 2015. Master Circular RBI/2014-15/91 DBOD.No.Ret.BC.11/12.01.001/2014-15 dated July 01, 2014. Reserve Bank of India, Mumbai, India.

Reserve Bank of India: 1988. Report of the Committee on the Financial System: a Summary. Reserve Bank of India Bulletin, July, Mumbai, India.

Schumpeter, J.A. 1911. The Theory of Economic Development. Cambridge, MA: Harvard University Press. 